\section{Albion Strawberry Responds to Mulch Treatments and Low Tunnels Covered with Photoselective Films}

\author{
Kaitlyn M. Orde \\ Department of Agriculture, Nutrition and Food Systems, University of \\ New Hampshire, 38 Academic Way, Durham, NH 03824
}

Rich Marini and Kathleen Demchak

Department of Horticulture, The Pennsylvania State University, Tyson Building, University Park, PA 16802

\section{Rebecca Sideman \\ Department of Agriculture, Nutrition and Food Systems, University of New Hampshire, 38 Academic Way, Durham, NH 03824} Additional index words. Fragaria $\times$ ananassa, everbearing, microtunnel, protected culture,
runner, soluble solids content

\begin{abstract}
The impact of photoselective films on strawberry plants in a low tunnel system has not been well investigated in the northeastern United States, nor have there been studies looking at the effect of mulch color in a plasticulture system. During two separate years (2016 and 2017), we evaluated 'Albion' in an annual system with three ground mulch treatments (black plastic, white-on-black plastic, and no plastic) and under six cover treatments. Five of the cover treatments were low tunnel films that varied in their ultraviolet, photosynthetically active, and near-infrared radiation transmission profiles: Tufflite IV $^{\text {TM }}$ (TIV), KoolLite Plus (KLP), Trioplast (TRP), and custom-manufactured UV-transparent (UVT) and UV-blocking (UVO) films. The sixth cover treatment was the traditional open bed environment (no low tunnel). 'Albion' produced fruit for 18 to 19 continuous weeks during both years until as late as Thanksgiving (24 Nov.) in 2016. Overall, the average marketable yield was greater in 2017 (486 g/plant) than in 2016 (350 g/plant), and it was greater on black mulch than on no mulch (445 vs. 380 g/plant, respectively); white mulch was intermediate $(419 \mathrm{~g} /$ plant $)(P \leq 0.05)$. There was not a significant increase in marketable yield under low tunnels compared with open beds. The average fruit mass was greater under KLP and UVO than open beds (TIV and UVT were intermediate), and greater on beds with no mulch than black mulch (white mulch was intermediate). Across cover treatments, plants on black mulch produced more runners than plants on white or no mulch, and the black mulch/open bed treatment generated the greatest number of runners in both years, more than double most other treatments in 2016. The present study demonstrates that mulch selection is important for maximizing the yield of 'Albion' in the Northeast region, and that both mulch and cover impact runnering and fruit size. For plant propagators producing 'Albion' tips in a field environment, the results of this study suggest they are likely to maximize runner quantity by cultivating plants on black mulch without low tunnel cover.
\end{abstract}

Small protective structures called low tunnels are used in strawberry (Fragaria $\times$ ananassa Duch.) production systems throughout the world (Ariza et al., 2012; Espí et al., 2006; Fagherazzi et al., 2017; Hancock and Simpson, 1995; Rosati, 1990; Singh et al., 2012), but have not yet been widely adopted in the United States, including the Northeast, where rain and hail during the fruiting season can cause significant crop loss. Recent research shows that compared to traditional open bed strawberry production, low tunnels reduce disease incidence, increase the percent marketable yield, and promote greater marketable yields during the shoulder seasons. Greater total yields and/or fewer runners per plant have also been realized (Anderson et al., 2019; Costa et al., 2017; Henschel et al., 2017; et al., 2006; Karlsson and Werner, 2011), and films that reduce or modify the red to far-red ratio (R/FR) (centered at $\approx 650$ and $730 \mathrm{~nm}$, respectively) can significantly affect plant morphology, development, and gene expression in strawberry (Folta and Childers, 2008). A low $\mathrm{R} / \mathrm{FR}$ ratio from shading or supplemental farred light has been shown to cause a number of plant responses in strawberry, including the elongation of stems, leaves, petioles, and the promotion of flowering (Collins, 1966; Zahedi and Sarikhani, 2016), and a high $\mathrm{R} / \mathrm{FR}$ ratio can result in more compact strawberry plants (Fletcher et al., 2004). Furthermore, plant exposure to ultraviolet (UV) radiation triggers the production of secondary metabolites involved in a number of important processes and compounds, including protective compounds that absorb potentially damaging UV rays in the epidermal tissue (Caputo et al., 2006; Kakani et al., 2003; Lamnatou and Chemisana, 2013; Mazza et al., 2000; Schreiner et al., 2017) and those that are responsible for the red color of strawberry fruit (Rein and Heinonen, 2004; Yoshioka et al., 2013). Greater anthocyanin, flavonoid, and/or phenolic contents have been reported for strawberry fruit produced under UV-transparent films than UV-blocking films, and UV-transparent conditions have been associated with a faster rate of color development (Henschel et al., 2017; Tsormpatsidis et al., 2011).

In the existing body of research related to photoselective films and strawberry production, films often differ in more than one region of the spectrum, making direct comparisons difficult. However, under medium protective structures (e.g., high tunnels), greater strawberry yields have been reported under films that transmitted higher percentages of UV-A, photosynthetically active radiation $(P A R)$, and NIR than under films that reduced transmission in one or more regions (Fletcher et al., 2004; Karlsson and Werner, 2011). Work by Karlsson and Werner (2011) showed that when two films with similar PAR transmission were compared, yields were greater under the film that transmitted UV-A and far-red than under the film that blocked UV-A and reduced far-red, indicating that $P A R$ alone was not the only driver of yield in the study. Greater early-season yields have also been reported under UVtransparent compared with UV-blocking (up to $380 \mathrm{~nm}$ ) films (Casal et al., 2009; Tsormpatsidis et al., 2011). A greater fruit mass but reduction in fruit number were found under UV-blocking films compared with UV-transparent films for short-day plants (Casal et al., 2009; Tsormpatsidis et al., 2011). Since the short-day flower buds were initiated long before the application of the photoselective films in the study, the reduction in fruit number was attributed to reduced pollinator activity, not to UV exposure (Tsormpatsidis et al., 2011).

There is limited work comparing photoselective films for low tunnels. In Quebec, Canada, 'Seascape' largely produced comparable yields under different films, with the exception of one year when higher yield under a 
particular film was attributed to $3 \%$ greater PAR transmission (Van Sterthem et al., 2017). In Maryland, Lewers et al. (2020) investigated the performance of multiple cultivars and photoselective films and reported that Albion tended to have above-average performance (compared with other films) under two films that blocked UV-B and had high PAR transmission. Interestingly, these films differed in their UV-A and NIR transmission substantially. In Minnesota, two experimental films that differed only in their UV transmission and were highly transmissive in the PAR and NIR ranges were compared and marketable yields were significantly greater under the UV-transparent films than the UV-blocking film in one of two years (Anderson et al., 2019; M. Rogers, personal communication). However, during the second year, yield was actually higher under the UV-blocking film, although not significantly (Anderson et al., 2019). In New York, a 1-year comparison of three commercially available films found yield was statistically comparable among films, but the authors made the observation that yield tended to increase with the level of UV-blockage (Willden et al., 2021).

It is worth mentioning that all aforementioned studies used dormant bare-rooted (frigo) plants, as is still common in the Northeast. Recent work by Pritts (personal communication) indicated that the developmental stage of plants at the time when they are covered by low tunnels impacts their response to films. Pritts found that a reduction in radiation was detrimental to yield from dormant bare-rooted 'Albion', but that plants started early in the greenhouse produced greater yields under low tunnel films that reduced

Received for publication 24 Mar. 2021. Accepted for publication 2 June 2021.

Published online 16 August 2021.

We thank Eric Hanson, Nigel Paul, and Edward Durner for providing thoughtful reviews of our manuscript, as well as Matthew Cooper at The Pennsylvania State University for his technical contributions. We thank Eric Hanson, Katherine Hanson, Marvin Pritts, Kim Lewers, and the rest of the TunnelBerries team, especially Nigel Paul of Lancaster University, Lancaster, United Kingdom, and Jason Moore of Arid Agritec, Ltd., for supplying the experimental films used for this and other studies during the TunnelBerries project.

This work was funded by the National Institute of Food and Agriculture, U.S. Department of Agriculture, Specialty Crops Research Initiative (award number 2014-51181-22380; TunnelBerries), as well as the New Hampshire Vegetable and Berry Growers' Association, the Pennsylvania Vegetable Growers Association, and Hatch Appropriations (project number PEN04590, accession number 1006805). Partial funding was provided by the New Hampshire Agricultural Experiment Station. This is Scientific Contribution Number 2878. This work was supported by the USDA National Institute of Food and Agriculture Hatch Project (project number NH00685 and accession number 1019868).

R.S. is the corresponding author. E-mail: becky.sideman@unh.edu.

This is an open access article distributed under the CC BY-NC-ND license (https://creativecommons. org/licenses/by-nc-nd/4.0/). light transmission during the growing season (Pritts, personal communication).

Interestingly, all published low tunnel studies with strawberry have used white (or white-on-black) plastic as the ground mulch (Anderson et al., 2019; Lewers et al., 2017, 2020; Petran et al., 2016; Willden et al., 2021), but black plastic mulch is the dominant mulch used for vegetable production in New Hampshire. Since northeastern growers have largely continued to rely on the perennial matted row system (Samtani et al., 2019), there has been limited research comparing black and white plastic mulches for plasticulture strawberry production. In the mid-Atlantic region of the United States, 'Albion' yields have been greater on white mulch than on black mulch (Durner, 2017), and soil temperatures tend to be cooler under white mulch than under black mulch (Lamont, 1993). Since root and fruit development are most successful at cool temperatures ( $\approx 12.8$ and $7.2^{\circ} \mathrm{C}$, respectively) (Galletta and Bringhurst, 1990), white may be more suitable in warm locations or conditions, such as during the summer months. However, increased soil temperatures under black mulch (Lamont, 1993) may be beneficial during plant establishment during the very cool and moist spring season in the Northeast, as well as during the autumn months when temperatures drop precipitously. Performance data for different mulches, as well as different low tunnel films, are needed for the Northeast region, especially as the interest in low tunnels grows.

The objectives of this study were to evaluate the effects of low tunnels covered with photoselective films in combination with different ground mulch treatments on strawberry yield, fruit mass, fruiting pattern over the season, runner production, soluble solids content (SSC), and the chroma, hue angle, and lightness of the skin color of fruit in order to better understand the impact materials have on strawberry yield and plant characteristics.

\section{Materials and methods}

\section{Site description and treatments}

Experiments were conducted at the University of New Hampshire's Woodman Horticultural Research Farm in Durham, NH (lat. $43^{\circ}$ N, U.S. Department of Agriculture Plant Hardiness Zone 5b) during the 2016 and 2017 growing seasons. New experiments were established in each year.

Three mulch treatments and six cover treatments were evaluated. The mulch treatments were 1.25 mil black plastic (black mulch), 1.25 mil white-on-black plastic (white mulch), and no plastic (no mulch). Cover treatments were the traditional unprotected field environment (open bed) and low tunnels covered by five plastic films selected to represent a diverse range of spectral transmission profiles available in commercial agricultural films (Table 1). Films varied in their thickness and transmission properties, as well as their age.

TIV, KLP, and TRP were selected from commercially available films based on their differences in light transmission characteristics and were acquired new in both years.
UVT and UVO were research-grade custommanufactured experimental films that were provided by collaborators at Arid AgriTec, Ltd. (Lancaster, UK) and were obtained to compare differences in UV-B and UV-A effects. UVT and UVO had been used at Michigan State University to cover high tunnels for 1 year prior to inclusion in the present study; therefore, UVT and UVO were in their second year and third year of use in 2016 and 2017, respectively. They had no visual defects. TRP was the only film manufactured specifically for low tunnels; it was added as a treatment in 2017. All films except TRP had to be cut to the correct size for the commercial low tunnel system used in experiments.

The transmission profiles of films are shown in Figure 1. TIV is marketed as a "high-clarity" film (Berry Global, 2020). UVT was slightly more transmissive than TIV, especially in the UV and lower PAR range. KLP is marketed as having increased thermicity to reduce heat loss, antifogging properties, and light diffusion (RKW Hyplast NV, 2015) and transmitted a high percent of $P A R$ but reduced NIR for a cooling effect (RKW Group, 2020; RKW Hyplast NV, 2015). UVO would be considered a UV-opaque film, as it blocked nearly all UV-A and UV-B. Compared with KLP, UVO had higher transmission in the $P A R$ and NIR ranges, and it also blocked UV-B. TRP had the highest percent transmission of all films, making it nearly transparent. The $\mathrm{R} / \mathrm{FR}$ ratio $(660 \mathrm{~nm} / 730 \mathrm{~nm})$ of films were calculated as 0.975 (TIV), 0.978 (UVT), 1.028 (KLP), 0.972 (UVO), and 0.997 (TRP). For comparison, the R/FR ratio on open beds has been reported to be 0.94 on black plastic and 1.0 on white plastic (Vincent et al., 2013).

The spectral transmission properties of films were mostly known prior to the onset of the study, but samples were collected at the end of both seasons and measured. Film samples measuring $8 \mathrm{~cm} \times 13 \mathrm{~cm}$ were cut from the top of each low tunnel replicate at the end of the 2016 and 2017 seasons. At the completion of the study in 2019, a spectroradiometer (PS-300; Apogee Instruments, Logan, UT) was used to calculate the percent transmission. Transmission profiles were recorded within $1 \mathrm{~h}$ of solar noon on a clear day in Rock Springs, PA (lat. $40.7^{\circ} \mathrm{N}$ ), oriented so the sensor was perpendicular to the sun. Paul et al. (2005) observed that as films age, UV transmission may increase for UV-blocking films and decrease for UV-transmitting films. Thus, since film samples were collected at the end of the growing season and not measured until the conclusion of the study, their transmission profiles may have differed slightly from when they were new. This is especially the case for UVT and UVO, which were reused for a total of 3 years in the present experiments.

\section{Experimental design}

A split-plot design with four complete blocks was used, where the main plot was 
Table 1. Cover treatments used to cover low tunnels at the University of New Hampshire in 2016 and 2017.

\begin{tabular}{|c|c|c|}
\hline $\begin{array}{l}\text { Low tunnel cover } \\
\text { treatment (abbreviation) }\end{array}$ & $\begin{array}{l}\text { Film } \\
\text { thickness }\end{array}$ & Manufacturer \\
\hline Tufflite IV TM (TIV) & 6 mil & Berry Global Inc., Evansville, IN \\
\hline KoolLite Plus (KLP) & 6 mil & RKW Hyplast NV, Hoogstraten, Belgium \\
\hline $\begin{array}{l}\text { Custom-manufactured } \\
\text { ultraviolet-transparent } \\
\text { (UVT) }\end{array}$ & 7.9 mil & $\begin{array}{l}\text { BPI-Visqueen, Stevenston, UK; currently available } \\
\text { through Lightworks Poly, Lancashire, UK }\end{array}$ \\
\hline $\begin{array}{l}\text { Custom-manufactured } \\
\text { ultraviolet-opaque } \\
\text { (UVO) }\end{array}$ & 7.9 mil & $\begin{array}{l}\text { BPI-Visqueen, Stevenston, UK; currently available } \\
\text { through Lightworks Poly, Lancashire, UK }\end{array}$ \\
\hline Trioplast (TRP) & 1.5 mil & Trioplast AB, Smalandsstenar, Sweden \\
\hline Open bed & $\mathrm{n} / \mathrm{a}$ & $\mathrm{n} / \mathrm{a}$ \\
\hline
\end{tabular}

mulch treatment, and the subplot was cover treatment. Each block contained three rows (one of each mulch treatment), and the six cover treatment subplots were randomized within each row. The cover treatment subplots were $3.3 \mathrm{~m}$ in length, contained 16 plants, and were separated by a distance of $\approx 3.1 \mathrm{~m}$.

One cultivar, Albion, was chosen for its establishment success and ability to fruit continuously through the summer and early fall in northern locations and high eating quality (Capocasa et al., 2017; Orde and Sideman, 2019a; Pritts and McDermott, 2017; Pike, 2011). 'Albion' is commonly referred to as "day-neutral," a term that is used by industry to distinguish repeat-fruiting cultivars from short-day cultivars. However, the term "dayneutral" may be technically inaccurate for 'Albion', as Durner (2017) found that long days enhance the yield and fruit number, suggesting the cultivar is a quantitative long-day plant. For this reason, some prefer the more general terms "remontant," "repeat fruiting," and "everbearing," but these terms are less widely known, may confuse growers, carry other associations, and/or may be used to refer to multiple plant types.

\section{Cultural practices}

Plants were treated as an annual crop. Based on soil test results and fertility recommendations for strawberry (Lantz et al., 2010; University of New Hampshire, 2016), the soil was amended with $67 \mathrm{~kg} \cdot \mathrm{ha}^{-1}$ of both nitrogen (N) [calcified ammonium nitrate $(22 \mathrm{~N}-0 \mathrm{P}-0 \mathrm{~K})$ ] and potassium $(\mathrm{K})$ [sulfate of potash-magnesia $(0 \mathrm{~N}-0 \mathrm{P}-18.3 \mathrm{~K})]$. No phosphorus $(\mathrm{P})$ was added. Raised beds measuring $10 \mathrm{~cm}$ high and $61 \mathrm{~cm}$ wide were laid at a bed-center spacing of $1.8 \mathrm{~m}$ and equipped with one center-buried drip irrigation line (T-tape; Rivulis Eurodrip, San Diego, CA). Dormant bare-rooted 'Albion' strawberry plants (Nourse Farms, Deerfield, MA) were planted during the spring of both years on 9 May 2016 and 28 Apr. 2017. Plants were planted in double staggered rows $30 \mathrm{~cm}$ apart with an in-row spacing of $40 \mathrm{~cm}$, resulting in a plant density of 32,292 plants/ha (based on 1.5-m bed center spacing) (Lantz et al., 2010). The first flush of flower trusses that emerged from plants was removed during both years to encourage successful plant establishment.

Additional fertility was supplied weekly with water through the drip irrigation system beginning in June of both years. In 2016, fertilizer was applied at a rate of $2.4 \mathrm{~kg} \cdot \mathrm{ha}^{-1} \mathrm{~N}$, $0.6 \mathrm{~kg} \cdot \mathrm{ha}^{-1} \mathrm{P}$, and $2.2 \mathrm{~kg} \cdot \mathrm{ha}^{-1} \mathrm{~K}$ per week; in 2017, it was applied at a slightly higher rate of $2.8 \mathrm{~kg} \cdot \mathrm{ha}^{-1} \mathrm{~N}, 0.7 \mathrm{~kg} \cdot \mathrm{ha}^{-1} \mathrm{P}$, and 2.7 $\mathrm{kg} \cdot \mathrm{ha}^{-1} \mathrm{~K}$ per week $(21 \mathrm{~N}-2.2 \mathrm{P}-16.6 \mathrm{~K}$; Jack's All Purpose LX $^{\mathrm{TM}}$ soluble fertilizer; JR Peters Inc., Allentown, PA). In July 2017, foliar nutrient analyses indicated that plants were below the optimal range of $\mathrm{N}$ and $\mathrm{P}$, and the application rates were increased in Aug. 2017 to $5.6 \mathrm{~kg} \cdot \mathrm{ha}^{-1} \mathrm{~N}, 1.3 \mathrm{~kg} \cdot \mathrm{ha}^{-1} \mathrm{P}$, and $5.3 \mathrm{~kg} \cdot \mathrm{ha}^{-1} \mathrm{~K}$.

Caterpillars feeding on establishing strawberry plants were controlled with $2.2 \mathrm{~kg} \cdot \mathrm{ha}^{-1}$ of Bacillus thuringiensis (DiPel DF; Valent BioSciences Corporation, Libertyville, IL) on 1 June 2016. High aphid populations during both years were managed with $0.3 \mathrm{~L} \cdot \mathrm{ha}^{-1}$ of acetamiprid (Assail 30 SG; United Phosphorus Co., King of Prussia, PA) on 28 June 2016 and 26 June 2017. Following the wilting and death of some plants in Oct. 2017, oriental beetle (Anomala orientalis) soil grubs were found and identified. It was too late in the season for effective treatment (Krischik and Davidson, 2013), and no measures were taken in this year. However, we closely monitored for adult oriental beetles in 2017; based on the pests' lifecycles, we conducted one targeted application of imidacloprid (Admire Pro; Bayer CropScience LP; Research Triangle Park, NC) systemically on 4 Aug. 2017. Fruit harvested during the 14-d preharvest interval were counted for yield purposes to reflect the productivity of plants in locations and years without the challenge posed by this pest.

\section{Low tunnel construction and management}

The TunnelFlex Retractable Low Tunnel System (Dubois Agrinovations, Saint-Rémi Quebec, CAN) was used, which consisted of steel low tunnel hoops measuring $0.7 \mathrm{~m}$ wide $\times 1.0 \mathrm{~m}$ high, steel anchor pipes measuring $3.2 \mathrm{~cm} \times 0.61 \mathrm{~m}$ for securing the film at the ends of the tunnels, steel grounding stakes measuring $0.46 \mathrm{~m}$ long to hold low tunnel hoops into the ground, and polyester bungee elastics to affix film to the low tunnel frame. Hoops were spaced at the manufacturer recommended spacing of $1.5 \mathrm{~m}$ apart, and the through drip irrigation at a rate of $0.7 \mathrm{~kg} \cdot \mathrm{ha}^{-1}$ film was cut to $2.4 \mathrm{~m} \times 6.1 \mathrm{~m}$, an appropriate size for low tunnel plots.

Low tunnels were constructed soon after planting in both years. Sides were immediately raised to the eave of the tunnel frame and remained fully vented throughout the spring and summer months. Low tunnels were oriented northwest to southeast. Once nighttime temperatures consistently dropped below $0{ }^{\circ} \mathrm{C}\left(32^{\circ} \mathrm{F}\right)$ during the fall, low tunnel sides were permanently lowered and only raised for harvest. This occurred on 10 Oct. 2016 and 29 Oct. 2017. With the exception of the relatively lightweight film TRP, low tunnel sides would only remain raised if manually rolled. Thus, it was not practical to lower the sides of TIV, KLP, UVT, and UVO for all precipitation events, and these films provided only overhead protection for rain during the spring and summer. Conversely, the sides of TRP tunnels were lowered for most rain events in 2017.

\section{Data collection}

Yield and fruit mass. Data were collected from the innermost 12 plants of each subplot, as terminal plants on both ends were considered guard plants. Fruit from all 12 plants were pooled together at harvest and later separated into marketable and unmarketable groups and weighed and counted by group. Mean yield per plant was calculated by dividing the total plot yield by the number of living plants for each date. Mean fruit weight was calculated by dividing the total plot yield by the number of fruits harvested. Fruit weighing less than $7.0 \mathrm{~g}$ were deemed unmarketable. Other reasons for unmarketability included water damage to fruit, a jelly-like texture, misshapen fruit, fruit covered by soil, and rot, including Botrytis cinerea or anthracnose fruit rots (Colletotrichum acutatum).

Soluble solids concentration. The SSC was measured in ${ }^{\circ}$ Brix on six dates in both years. Ten strawberries (or the available quantity) from each plot were randomly selected at harvest to be individually measured for SSC. Fruit were placed into a plastic bag, sealed, and frozen at $-18^{\circ} \mathrm{C}$. Bags were later removed from the freezer, thawed at room temperature for $2 \mathrm{~h}$, and sap was extracted by squeezing the fruit between two fingers until $\approx 1 \mathrm{~mL}$ of sap covered the lens of a refractometer (Milwaukee Instruments, Inc., Rocky Mount, NC, in 2016; and Model HI96801, Hanna Instruments, Woonsocket, RI, in 2017). All 10 fruits sampled on a given date were averaged to determine a mean subplot value.

Fruit surface color. On six dates in 2016, 10 fruit from each subplot were randomly selected at harvest and $L, a$, and $b$ values were recorded using a photospectrometer (Chroma Meter CR-400 with Color Data Software CM-S100w SpectraMagin NX Ver. 2.6; Konica Minolta, Tokyo, Japan). $a^{*}$ and $b^{*}$ values were converted to chroma and hue angle (McGuire, 1992).

Runner numbers. Runners were removed from plants and counted biweekly. The mean 
number of runners per plant was calculated by dividing the total number of runners per subplot by the number of living plants in each subplot.

Plant height and diameter. Plant height and diameter were recorded on 21 Nov. 2017 , by measuring from the base of the plant to the tallest and widest point of living foliage (including flower trusses). Plant diameter (including petioles and leaves) was measured parallel to the edge of the raised bed.

\section{Statistical analysis}

Initially, the total marketable yield per plot was analyzed by analysis of variance (ANOVA) with SAS Proc Mixed as a split plot with a three-way factorial treatment structure ( 2 years, 3 mulches, and 5 covers with TRP deleted). Year and mulch were the only variables that were significant at the $5 \%$ level. Since there was an additional cover in 2017, data for each year were subjected to ANOVA. The main effects were sometimes significant, but the interaction of mulch $\times$ cover was not; thus, main effect least significant (LS) means were compared with the SIMULATE adjustment at the 5\% level. The same approach was used to analyze data for chroma, hue angle, lightness, runner number, and plant height and diameter. Cumulative yield per plot was calculated for each harvest date each year and subjected to a repeated measures analysis using SAS Proc Glimmix. The three-way interaction of the day of the year $\times$ cover $\times$ mulch was not significant. Since the two-way interaction of the day of the year $\times$ cover and the day of the year $\times$ mulch were significant, the SLICEBY option was included in the LS means statement to compare covers or mulches within each day of the year at the 5\% level. Average marketable yield per plant was calculated for each combination of mulch and cover for both years and plotted against each other to determine if the same combinations tended to have high yields during both years. Then, the average yields for each combination were ranked each year, and the ranks were correlated with Spearman's rank correlation with
SAS Proc Corr. In 2016, oriental beetle damage resulted in the loss of one replicate of black mulch/TIV, black mulch/KLP, white mulch/UVT, and white mulch/KLP, and two replicates of white mulch/open bed. These replicates were excluded from the total marketable yield data, resulting in $n=3(n=2$ for white mulch/open bed) for these mulch/ cover treatments in this year only.

\section{Results}

'Albion' plants started producing ripe fruit on 14 July 2016 and 28 June 2017, $\approx 9$ weeks after planting in each year. Fruit harvests continued until 14 Nov. 2016 and 8 Nov. 2017, for a total of 18 and 19 weeks of fruit production in 2016 and 2017, respectively. Oriental beetle grubs caused wilting, discoloration, and the loss of some plants in 2016, but not in 2017 due to proactive treatment.

Yield. When both years were combined, year $(P<0.0001)$ and mulch treatment $(P<$ $0.001)$ affected cumulative annual marketable yield. The average marketable yield was greater in 2017 (486 g/plant) than 2016 (350 g/plant) (Table 2), and it was greater on beds with black mulch than on beds with no mulch (445 vs. $380 \mathrm{~g} /$ plant, respectively); white mulch was intermediate (419 g/plant) (data not shown) $(P \leq 0.05)$. Cover treatments did not impact yield and there were no significant treatment interactions.

To include the TRP cover treatment that was present only in the 2017 experiment, yield data were also analyzed separately by year. In 2016, marketable yield ranged from $266 \mathrm{~g} /$ plant (white mulch/open bed) to $428 \mathrm{~g} /$ plant (black mulch/UVT), and neither mulch nor cover affected the cumulative marketable yield $(P>0.05)$ (Table 2). In 2017, the yield ranged from $309 \mathrm{~g} /$ plant (no mulch/open bed) to $579 \mathrm{~g} /$ plant (black mulch/KLP), and eight of the 18 treatment combinations exceeded $500 \mathrm{~g} /$ plant of marketable yield. Mulch affected cumulative marketable yield during this year $(P<0.001)$, and yield was higher on black mulch than no mulch (533 vs. $433 \mathrm{~g}$ / plant, respectively) ( $P \leq 0.05)$; white mulch was intermediate (493 g/plant) (Table 2).

Marketable yield for all mulch/cover treatments in 2016 and 2017 were plotted against each other (Fig. 2), which showed that no mulch/open bed had low yield in both years, and that black mulch/TIV, black mulch/UVT, white mulch/KLP, and white mulch/UVO had comparatively high yields during both years. When the total marketable yield of the 15 treatments shown in Fig. 2 were ranked from low to high for both years and correlated, Rho $=0.50$ and $P=0.049$, indicating a significant relationship between years and demonstrating that the mulch/cover combinations with high yields in 2016 also tended to have high yields in 2017.

Monthly yield. Monthly marketable yields are shown in Fig. 3 to illustrate the fruiting pattern of 'Albion' in New Hampshire during these two seasons. The total monthly marketable yields increased each month until August or September, when production reached its peak for all treatments. On beds without plastic mulch, marketable yields peaked in August and then declined, whereas the marketable yield on plastic-mulched beds continued to increase or remain high until September (with the exception of black mulch in 2017) (Fig. 3). The fruiting pattern was very similar among cover treatments in both years, except for KLP in 2017, which was notably high yielding.

Fruit weight. Year $(P<0.0001)$, mulch $(P<0.0001)$, and cover $(P<0.05)$ affected the season-long average fruit weight. The average fruit weight was greater in 2017 (15.2 g/ fruit) than in 2016 (11.3 g/fruit), and it was greater on beds with no mulch (13.9 g/fruit) beds with black mulch $(12.6 \mathrm{~g} /$ fruit $)(P<0.05)$; the average fruit weight on white mulch was intermediate (Table 3). KLP (13.9 g/fruit) and UVO (13.6 g/fruit) had the highest average fruit weight, which was greater than open beds (12.5 g/fruit); UVT and TIV were intermediate $(P<0.05)$ (Table 3). When the two years were separated to include TRP, the main effects did not impact fruit weight in 2016, but did in 2017, when fruit weighed more on white mulch

Table 2. Mulch and cover treatment effects on cumulative marketable yield (g/plant) at the University of New Hampshire in 2016 and 2017. Cover treatments were Tufflite IV ${ }^{\mathrm{TM}}$ (TIV), KoolLite Plus (KLP), Trioplast (TRP), custom-manufactured ultraviolet-transparent (UVT) and ultraviolet-opaque (UVO) films, and traditional open beds. New (unused) TIV, KLP and TRP films covered low tunnels in both years; UVT and UVO were used for two and three seasons in 2016 and 2017, respectively.

\begin{tabular}{|c|c|c|c|c|c|c|c|c|}
\hline \multirow[b]{2}{*}{ Treatment } & \multicolumn{4}{|c|}{2016} & \multicolumn{4}{|c|}{2017} \\
\hline & Black mulch & White mulch & No mulch & Cover mean & Black mulch & White mulch & No mulch & Cover mean \\
\hline TIV & 374 & 314 & 295 & 328 & 551 & 447 & 434 & 478 \\
\hline KLP & 329 & 387 & 344 & 353 & 579 & 541 & 519 & 546 \\
\hline UVO & 358 & 389 & 362 & 370 & 469 & 535 & 449 & 484 \\
\hline TRP & - & - & - & - & 559 & 506 & 436 & 500 \\
\hline Open bed & 359 & 266 & 310 & 312 & 548 & 485 & 309 & 447 \\
\hline Cover & \multicolumn{3}{|c|}{0.14} & & & \multicolumn{2}{|c|}{0.071} & \\
\hline Mulch $\times$ cover & \multicolumn{3}{|c|}{0.55} & & & \multicolumn{2}{|c|}{0.21} & \\
\hline
\end{tabular}

${ }^{\mathrm{z}}$ Year means followed by the same uppercase letters do not differ at the $5 \%$ level of significance according to the SIMULATE adjustment.

${ }^{\mathrm{y}}$ Mulch means followed by the same lowercase letters do not differ at the $5 \%$ level of significance according to the SIMULATE adjustment.

ANOVA $=$ analysis of variance. 
2016

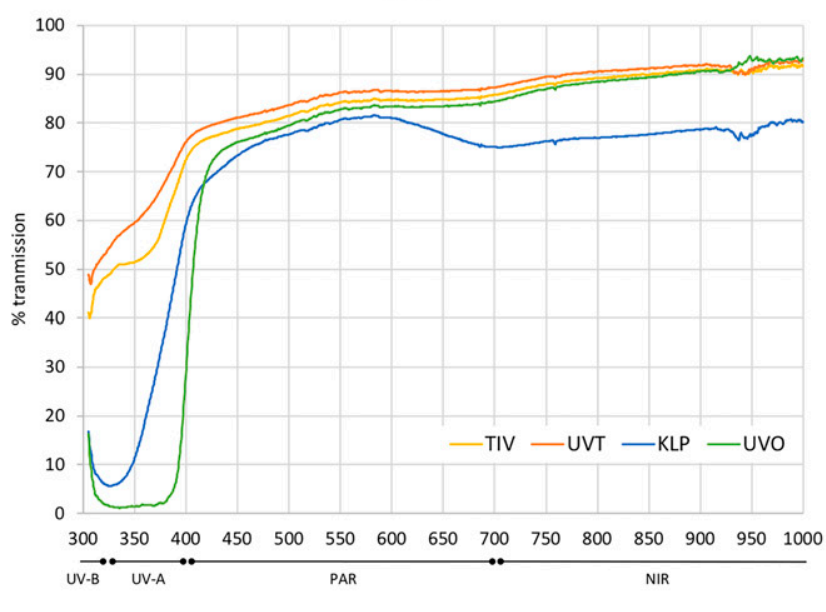

Wavelength in nanometers ( $\mathrm{nm}$ )
2017

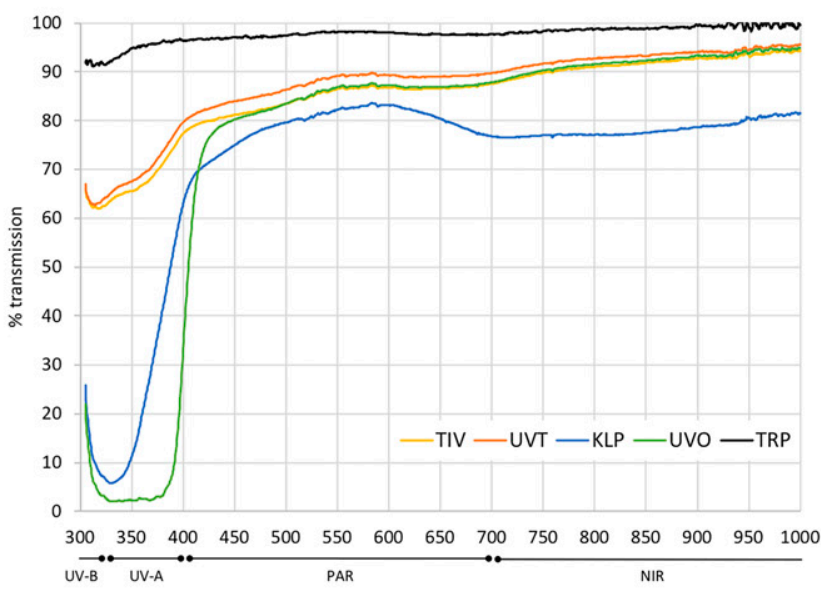

Wavelength in nanometers ( $\mathrm{nm}$ )

Fig. 1. Percent transmission of ultraviolet-B (UV-B), ultraviolet-A (UV-A), photosynthetically active radiation (PAR), and near-infrared (NIR) radiation of films used to cover low tunnels at the University of New Hampshire in 2016 and 2017. Transmission profiles were measured from film samples collected at the end of both growing seasons. New (unused) Tufflite IV ${ }^{\mathrm{TM}}$ (TIV), KoolLite Plus (KLP), and Trioplast (TRP) films were used in 2016 and 2017 , whereas the custom-manufactured ultraviolet-transparent (UVT) and ultraviolet-opaque (UVO) experimental films were reused and used for a total of two and three growing seasons in 2016 and 2017, respectively. Percent transmission data were provided by Matthew Cooper at The Pennsylvania University; they were recorded at solar noon on a clear day in Rock Springs, PA, using a spectroradiometer (PS-300; Apogee Instruments, Logan, UT) $(\mathrm{n}=12$ ).

$(15.4 \mathrm{~g} /$ fruit $)$ and no mulch $(16.0 \mathrm{~g} /$ fruit $)$ than black mulch $(14.4 \mathrm{~g} /$ fruit $)(P<0.05)$. Fruit mass was also greater under KLP, UVO, and UVT than open beds (Table 3 ).

Soluble solids content. Season-long average SSC was affected by year $(P<0.001)$ and was greater in $2016(9.6 \%)$ than $2017(9.3 \%)$ (data not shown). A repeated measure analyses showed that within the year, neither mulch nor cover treatment affected SSC. In both years, the average SSC was highest under TIV, but there were no statistically significant differences between TIV and the other cover treatments.

Fruit surface color. Chroma, hue angle, and lightness $\left(\mathrm{L}^{*}\right)$ measurements collected at six dates in 2016 were not affected by mulch or cover treatments. There was little variation in mean values among treatments and between main effects for each of the variables. The grand mean values were 21.1 for chroma, 12.9 for hue angle, and 36.5 for lightness.

Runner numbers. In 2016, mulch $(P<$ $0.0001)$ and cover $(P<0.0001)$ affected the cumulative number of runners produced per plant, and a significant mulch $\times$ cover interaction $(P<0.01)$ occurred. During this year, 'Albion' on black mulch produced double the number of runners per plant on open beds (10.3 runners) than that under low tunnels (average of 5.0 runners) (Fig. 4). Furthermore, on open beds, plants on black mulch had more runners than plants on white mulch

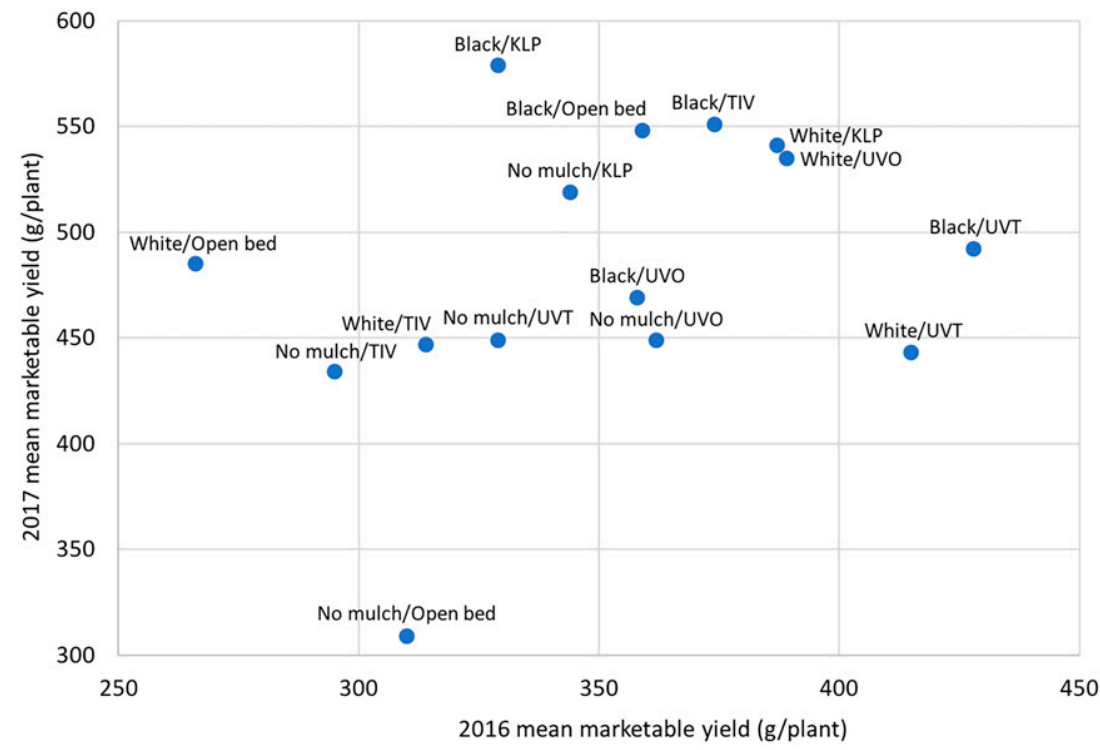

Fig. 2. Marketable yield of mulch and cover treatment combinations in 2016 and 2017, plotted against each other. Mulch treatments were black plastic, white-on-black plastic, and no mulch (bare ground). Cover treatments were traditional open beds (open) and low tunnels covered with Tufflite IV ${ }^{\mathrm{TM}}$ (TIV), KoolLite Plus (KLP), and custom-manufactured ultraviolet-transparent (UVT) and ultraviolet-opaque (UVO) experimental films. Trioplast (TRP) was excluded because it was only present during the 2017 experiment.
(5.6 runners/plant) and no mulch (5.1 runners/plant $)(P<0.05)$. For TIV, KLP, UVT, and UVO, plants produced a comparable number of runners regardless of mulch.

In 2017, only mulch $(P<0.0001)$ affected the runner counts, and plants on black mulch produced more runners (6.1 runners/plant) than plants on white mulch (4.5 runners/plant) and no mulch (3.3 runners/plant) $(P<0.05)$; plants on white mulch also produced more runners than beds with no mulch $(P<0.05)$ (data not shown). Comparisons of cover treatment within each mulch treatment, as well as mulch treatment within each cover treatment, showed that the black mulch/open bed treatment produced the greatest number of runners of all treatment combinations (8.2 runners/ plant); a number greater than all other cover treatments on black mulch $(P<0.05)$ and more than that on white mulch and no-mulch open bed treatments (Fig. 4).

Plant height and diameter. Mulch treatment affected the plant height and diameter in $2017(P<0.05)$, the only year when measurements were collected, and plants on black mulch were both taller and wider than plants grown on beds with no mulch $(P \leq 0.05)$ (Table 4$)$. Cover treatment influenced plant diameter, but not plant height, and plants were wider under TIV $(32.9 \mathrm{~cm})$ than on open beds $(28.7 \mathrm{~cm})$, with all other cover treatments intermediate in width $(P$ $\leq 0.05$ ) (Table 4). A marginally significant mulch $\times$ cover interaction occurred for plant diameter $(P=0.05)$ due to the fact that cover treatment did not affect plant diameter on white mulch, but on black mulch and no mulch, plant diameter was smaller under UVO and open beds, respectively.

\section{Discussion}

In New Hampshire, the short-day strawberry season begins in early or mid-June and lasts for $\approx 1$ month. In the present study, the 

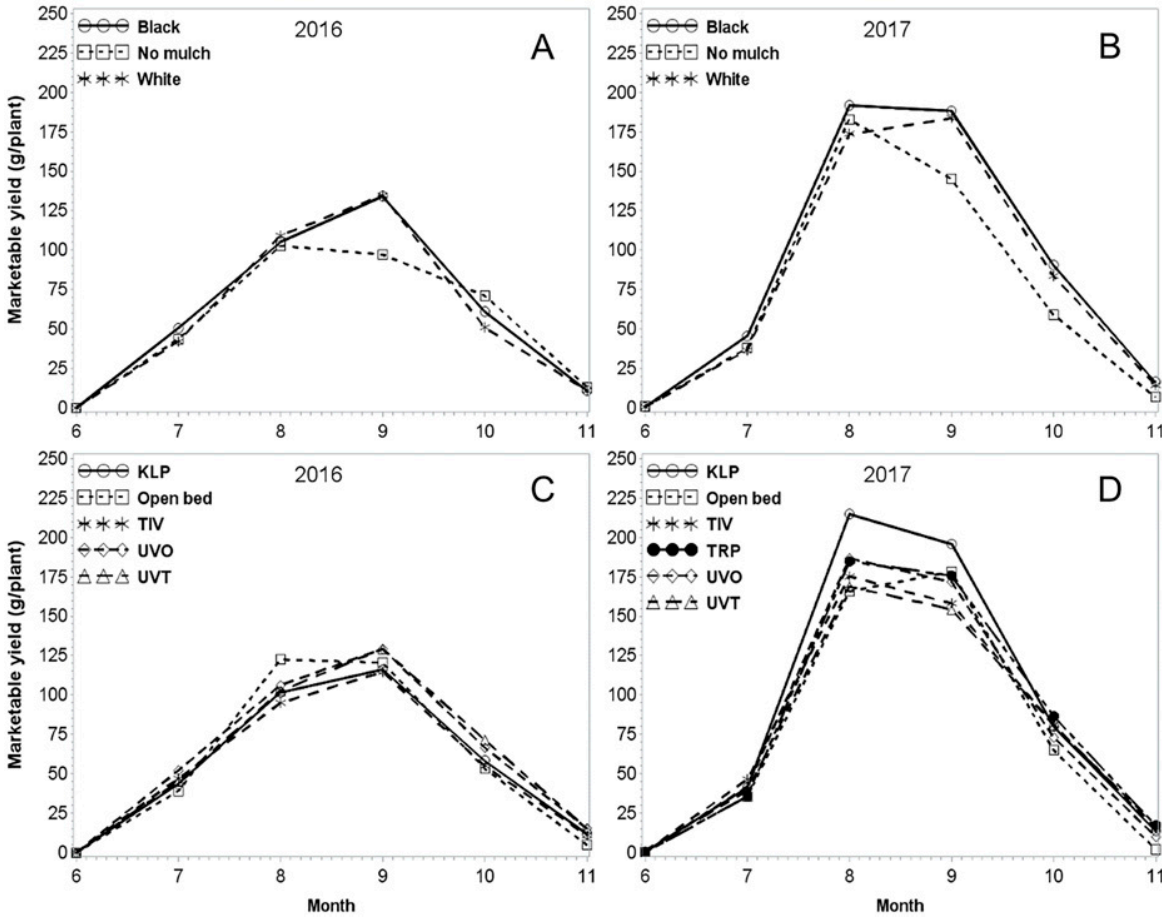

Fig. 3. Mulch and cover effects on the total monthly marketable yield (g/plant) of 'Albion' plants in Durham, NH, for mulch treatment in 2016 (A) and 2017 (B), and cover treatment in 2016 (C) and 2017 (D). The month number on the x-axis refers to June (6) through November (11). Mulch treatments were black plastic mulch, white-on-black plastic mulch, and no mulch (bare ground). Cover treatments were traditional open beds (open) and low tunnels covered with Tufflite IV ${ }^{\mathrm{TM}}$ (TIV), KoolLite Plus (KLP), Trioplast (TRP), and custom-manufactured ultraviolet-transparent (UVT) and ultraviolet-opaque (UVO) experimental films.

day-neutral cultivar Albion fruited from midJuly until November, demonstrating that when Albion is coupled with the existing short-day crop, the locally produced strawberry crop can be extended to over 5 months annually. Furthermore, the fact that 'Albion'

produced peak yields in August and September indicates that plasticulture production of this cultivar provides a solid late-summer and fall fruit crop for northeastern growers.

The marketable yields presented in this study ranged from $11,300 \mathrm{~kg} \cdot \mathrm{ha}^{-1}$ to 15,700

Table 3. Mulch and cover treatment effects on mean fruit weight (g/fruit) at the University of New Hampshire in 2016 and 2017. Cover treatments were Tufflite IV ${ }^{\mathrm{TM}}$ (TIV), KoolLite Plus (KLP), Trioplast (TRP), custom-manufactured ultraviolet-transparent (UVT) and ultraviolet-opaque (UVO) films, and traditional open beds. New (unused) TIV, KLP and TRP films covered low tunnels in both years; UVT and UVO were used for two and three seasons in 2016 and 2017, respectively.

\begin{tabular}{|c|c|c|c|}
\hline & Both years combined ${ }^{\mathrm{z}}$ & 2016 & 2017 \\
\hline \multicolumn{4}{|l|}{ Mulch } \\
\hline Black plastic & $12.6 b^{y}$ & 10.8 & $14.4 \mathrm{~b}$ \\
\hline White plastic & $13.3 \mathrm{ab}$ & 11.1 & $15.4 \mathrm{a}$ \\
\hline No mulch & $13.9 \mathrm{a}$ & 11.8 & $16.0 \mathrm{a}$ \\
\hline \multicolumn{4}{|l|}{ Cover } \\
\hline TIV & $13.1 \mathrm{ab}$ & 11.0 & $15.1 \mathrm{ab}$ \\
\hline KLP & $13.9 \mathrm{a}$ & 11.6 & $16.1 \mathrm{a}$ \\
\hline UVT & $13.3 \mathrm{ab}$ & 11.2 & $15.4 \mathrm{a}$ \\
\hline UVO & $13.6 \mathrm{a}$ & 11.6 & $15.6 \mathrm{a}$ \\
\hline Open bed & $12.5 \mathrm{~b}$ & 10.9 & $14.1 \mathrm{~b}$ \\
\hline TRP & & & $15.3 \mathrm{ab}$ \\
\hline \multicolumn{4}{|c|}{ ANOVA $P$ values } \\
\hline Year & 0.0001 & & \\
\hline Mulch & 0.0001 & 0.12 & $<0.0001$ \\
\hline Cover & 0.013 & 0.71 & 0.001 \\
\hline Mulch $\times$ cover & 0.84 & 0.54 & 0.98 \\
\hline Year $\times$ mulch & 0.47 & & \\
\hline Year $\times$ cover & 0.51 & & \\
\hline Year $\times$ mulch $\times$ cover & 0.49 & & \\
\hline
\end{tabular}

${ }^{\mathrm{z}}$ Does not include TRP cover treatment present only during the 2017 experiment.

${ }^{\mathrm{y}}$ Within-row and variable means followed by the same letters do not differ at the $5 \%$ level of significance according to the SIMULATE adjustment.

ANOVA $=$ analysis of variance. $\mathrm{kg} \cdot \mathrm{ha}^{-1}$. These values are noteworthy because they are substantially greater than the $5900 \mathrm{lb} /$ acre $\left(6600 \mathrm{~kg} \cdot \mathrm{ha}^{-1}\right)$ that has been reported by commercial growers in the Northeast region, presumably from the matted-row short-day system (Samtani et al., 2019; U.S. Department of Agriculture National Agricultural Statistics Service, 2018). This suggests there is real potential to increase per-acre yield through the adoption of plasticulture and the cultivar Albion. The greater yields observed in 2017 compared with those in 2016 may be related to the higher $\mathrm{N}$ fertility rate. Where plants were fertigated with $2.4 \mathrm{~kg} \cdot \mathrm{ha}^{-1}$ per week in 2016 , this rate increased to $2.8 \mathrm{~kg} \cdot \mathrm{ha}^{-1}$ per week in Spring 2017, and then to $5.6 \mathrm{~kg} \cdot \mathrm{ha}^{-1}$ per week in Aug. 2017. The marketable yield of 'Albion' has been shown to increase with the $\mathrm{N}$ rate (Durner, 2017; Mays and $\mathrm{Gu}$, 2018), and the cultivar has a reputation as a heavy $\mathrm{N}$ feeder. Additionally, while plants killed by oriental beetle grubs in 2016 were excluded from analyses, it is likely that the grubs were present in the soil elsewhere during the experiment and may have negatively impacted the health and productivity of additional plants through their feeding activity. Therefore, preemptive management of this pest in 2017 may have also contributed to 2017 being a higher-yielding season.

Mulch treatment. Black mulch significantly increased marketable yields compared with no mulch in the present study, and white mulch also increased average marketable yield compared with no mulch, indicating that for day-neutral cultivars in their first year of fruit production, plastic mulch is an effective tool for increasing marketable yields. While the present study compared plastic mulched beds with completely bare beds, Petran et al. (2016) found that white plastic mulched beds also tended to increase yield compared with straw mulch beds, which are used in the perennial matted row system popular throughout the Northeast (Samtani et al., 2019).

It has been estimated that strawberry production on plastic mulch can be three-times more profitable than that of the matted row system (Fiola, 1995). In the present study, plants produced an average of $4650 \mathrm{~kg} \cdot \mathrm{ha}^{-1}$ of added marketable yield on black mulch than on beds without plastic mulch. The additional upfront material cost of the black plastic was $\$ 727 / \mathrm{ha}$ (assuming $1.5-\mathrm{m}$ bed centers), but resulted in additional revenue between $\$ 26,654 / \mathrm{ha}$ (at $\$ 5.73 / \mathrm{kg}$ ) (U.S. Department of Agriculture National Agricultural Statistics Service, 2018) and $\$ 46,128 / \mathrm{ha}$ (at $\$ 9.92 / \mathrm{kg}$ or $\$ 6.75 / \mathrm{qt}$ ), depending on the market price. Labor, machinery, and mulch disposal costs (estimated at \$250/ha) (Shogren and Hochmuth, 2004) also need to be considered.

Northeastern growers have not yet widely adopted plastic mulch for strawberry production (Samtani et al., 2019), but there has been some adoption, mostly to assist with weed management. The lack of adoption is likely the result of a myriad of factors, including regional comfort and identity with the matted row system, the feeling that labor inputs for 


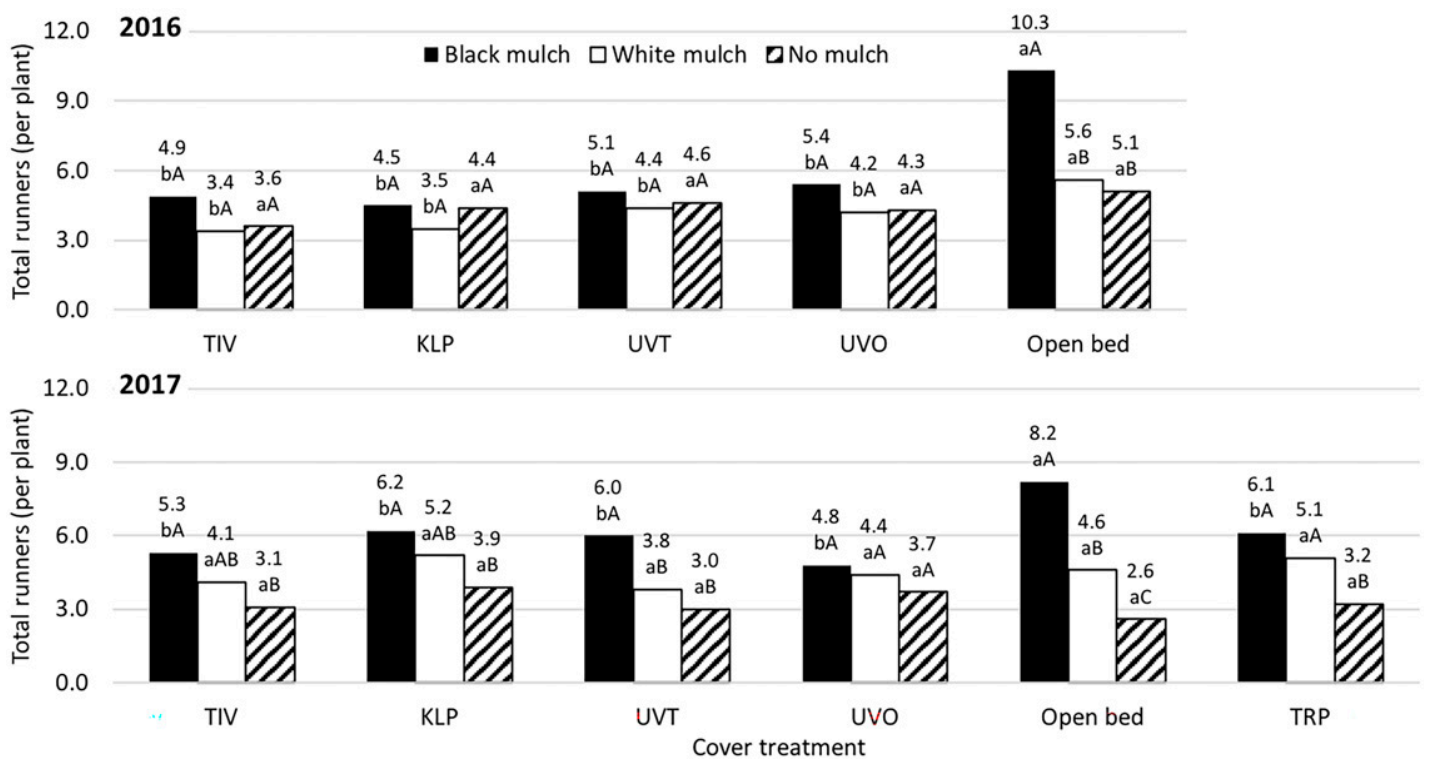

Fig. 4. Mulch and cover treatment effects on the cumulative number runners per 'Albion' plant in 2016 and 2017, in Durham, NH. Mulch treatments were black plastic, white-on-black plastic, and no mulch (bare ground). Cover treatments were traditional open beds and low tunnels covered with Tufflite IV $^{\mathrm{TM}}$ (TIV), KoolLite Plus (KLP), Trioplast (TRP), and custom-manufactured ultraviolet-transparent (UVT) and ultraviolet-opaque (UVO) experimental films. Within-year and mulch treatment means followed by the same lowercase letters do not differ at the $5 \%$ level of significance according to SLICEDIFF with PROC GLIMMIX. Within-year and cover treatment means followed by the same uppercase letters do not differ at the $5 \%$ level of significance according to SLICEDIFF with PROC GLIMMIX.

the matted row system complement other seasonal demands on highly diversified farms, concern that water may pool on plastic under fruit, and labor for runner removal. Some also feel that the initial costs of the plasticulture system are both too high and greater than the cost of the matted row system. However, recent estimates have found that when the entire period and all expenses are considered (nonharvest labor, harvest labor, materials, and equipment), the costs to establish and maintain a matted-row system may actually be $30 \%$ greater than that of the plasticulture tages of the plasticulture system (superior weed control, increased efficiency when system (Kochka, 2016). Ironically, the advan-

harvesting, and added control over irrigation and fertility applications) (Pritts and Handley, 1998) have driven the pervasive adoption of plasticulture for annual vegetable production across the region, including on many of the same farms that have not adopted plasticulture for strawberry production. Northeastern farms do have highly unique and personalized growing practices, and the annual plasticulture system used in other regions may not be the best fit for all operations. However, for farms already using plasticulture for annual crops, it is unlikely that the system is costprohibitive, especially because strawberry is considered "one of the most profitable crops on a per acre basis" (Fiola, 1995). This and

Table 4. Mulch and cover effects on the average height and diameter of 'Albion' plants at the end of the 2017 growing season. Measurements were collected on 21 Nov. 2017.

\begin{tabular}{|c|c|c|c|c|c|c|c|c|}
\hline \multirow[b]{2}{*}{ Cover } & \multicolumn{4}{|c|}{ Plant ht $(\mathrm{cm})$} & \multicolumn{4}{|c|}{ Plant diam $(\mathrm{cm})$} \\
\hline & Black & White & No mulch & Mean & Black & White & No mulch & Mean \\
\hline$\overline{\mathrm{TIV}}$ & 16 & 14 & 14 & 14 & $36 \mathrm{aA}^{\mathrm{yx}}$ & $31 \mathrm{aB}$ & $31 \mathrm{aB}$ & $33 \mathrm{a}$ \\
\hline KLP & 16 & 14 & 14 & 15 & $35 \mathrm{abA}$ & $29 \mathrm{aB}$ & $31 \mathrm{aB}$ & $32 \mathrm{ab}$ \\
\hline UVT & 16 & 13 & 14 & 14 & $34 \mathrm{abA}$ & $30 \mathrm{aA}$ & $32 \mathrm{aA}$ & $32 a b$ \\
\hline UVO & 15 & 14 & 13 & 14 & $32 \mathrm{bA}$ & $32 \mathrm{aA}$ & $32 \mathrm{aA}$ & $32 a b$ \\
\hline TRP & 14 & 14 & 12 & 13 & $33 \mathrm{abA}$ & $31 \mathrm{aA}$ & $30 \mathrm{aA}$ & $31 \mathrm{ab}^{\mathrm{v}}$ \\
\hline Open bed & 16 & 14 & 12 & 14 & $33 \mathrm{abA}$ & $30 \mathrm{aA}$ & $23 \mathrm{bB}$ & $29 \mathrm{~b}$ \\
\hline Mean & $16 \mathrm{a}^{\mathrm{z}}$ & $14 \mathrm{ab}$ & $13 \mathrm{~b}$ & & $34 \mathrm{a}$ & $31 \mathrm{ab}$ & $30 \mathrm{~b}$ & \\
\hline Mulch & \multicolumn{4}{|c|}{0.020} & \multicolumn{4}{|c|}{0.032} \\
\hline Cover & \multicolumn{4}{|c|}{0.63} & \multicolumn{4}{|c|}{0.048} \\
\hline Mulch $\times$ cover & \multicolumn{4}{|c|}{0.82} & \multicolumn{4}{|c|}{0.049} \\
\hline
\end{tabular}

${ }^{\mathrm{z}}$ Within-row and variable main effect means followed by the same letters do not differ at the $5 \%$ level of significance according to the SIMULATE adjustment.

${ }^{y}$ Within columns, mulch means followed by the same lowercase letters do not differ at the $5 \%$ level according to slicediff in Glimmix.

${ }^{\mathrm{x}}$ Within rows, cover means followed by the same uppercase letters do not differ at the $5 \%$ level of significance according to slicediff in Glimmix.

${ }^{\mathrm{w}}$ Within-column main effect means followed by the same letters do not differ at the $5 \%$ level of significance according to the SIMULATE adjustment.

ANOVA $=$ analysis of variance. other research continue to suggest the potential for increasing yield and revenue through the adoption and adaptation of plasticulture in the Northeast. There are already successful modifications to the system that can be found in the region.

Low tunnels and film treatments. The results of the current study are consistent with those of other works that failed to find statistically significant differences in yield between strawberry plantings on open beds and under low tunnels (Petran et al., 2016; Van Sterthem et al., 2017). However, in both years of experiments in our location, average marketable yields were greater under all low tunnel films compared with the open bed treatment, especially on white mulch and unmulched beds. The increase in yield under low tunnels ranged from 24 to $70 \mathrm{~g} /$ plant or 773 to $2260 \mathrm{~kg} \cdot \mathrm{ha}^{-1}$, depending on the mulch/cover combination. This suggests that while the increased yield we observed under low tunnels was not quite significant at the $5 \%$ level, it may still be economically meaningful for growers in some situations.

We found that the thickness of the TIV, KLP, UVT, and UVO films made adapting these films for use in a low tunnel system challenging. TIV, KLP, UVT, and UVO would not remain raised if sides were lifted (or "scrunched") upward; instead, it was necessary for the sides to be rolled under and upward in segments to keep tunnels vented. This method made adjusting ventilation prohibitively time-consuming with these thicker films. TRP, however, was highly compatible with the low tunnel system, as it remained raised when lifted and was easy to adjust before and after precipitation. We believe this is one factor that contributed to high 
marketable yields under this cover treatment across all mulch treatments in 2017.

Previous work with photoselective films suggested that we may find differences in yield or fruit size among low tunnel films. Similar to the findings by Casal et al. (2009) and Tsormpatsidis et al. (2011), fruit weight was highest under the UV-blocking films UVO and KLP, significantly higher than the open bed cover treatment when both years were analyzed together, as well as in 2017. In terms of yield, we found that the moderate and highly transmissive films (TIV, UVT, and TRP) produced yields comparable to those of films that blocked or reduced UV and NIR (KLP and UVO).

We wish to draw attention to a notable trend related to mulch/cover combination, however. When 'Albion' was grown on black mulch, yields tended to be greatest under the cover treatments that transmitted the highest percent of UV, PAR, and NIR (namely, TIV, UVT, TRP, and open beds). However, when plants were grown on white mulch, yields were consistently highest under the UVreducing films KLP and UVO (the former also reduced NIR transmission). One-off exceptions to this trend were white mulch/ UVT, white mulch/TRP, and black mulch/ KLP, which each performed very well during one of two years [above average plant performance under KLP has also been reported by (Lewers et al. 2020)]. This trend may suggest an interaction between the reflectance and absorption properties of the mulches and the transmission profiles of films. The fact that during both years, average yields under TIV, UVT, and TRP were lower on white than on black mulch suggests that white mulch modified the environment in a detrimental way under these films. A potential explanation may be the combination of moderate to high UV transmission through the films and high UV reflectivity on the white mulch (Bais et al., 2015). Conversely, when KLP and UVO covered white mulch, they likely reduced UV exposure for plants.

It is important to note that it is unlikely that any plants in the study were grown in the absence of UV, or under UV "blocked" conditions, even under the UV-limiting or UVblocking films. In addition to the fact that these films did not block $100 \%$ of UV radiation (Fig. 1), the sides of the low tunnel structures were raised for the majority of the growing season, which allowed ambient radiation to easily reach plants regardless of film treatment. Anderson et al. (2019) found significantly less UV radiation under UVO than under UVT, but the authors only raised the sides of low tunnels $\approx 12$ inches above the ground to create a more protective environment for plants. This was different from the approach taken in this research: low tunnel sides were raised to the eave of the tunnel to provide maximum ventilation and films primarily provided overhead coverage only, unless they were closed.

All previous low tunnel studies that we are aware of grew plants on white plastic mulch. On this mulch color, Lewers et al.
(2020) reported that 'Albion' performed best under KLP and under a relatively transparent film that had transmission properties similar to those of TRP. While there were no statistically significant differences in yield on white mulch among films in the present study, which aligns with other work (Willden et al., 2021), the average yields on white mulch were greatest under KLP, UVO, and TRP, indicating that our findings related to the best film for 'Albion' on white mulch are strikingly similar to those of Lewers et al. (2020). Also on white mulch, Willden et al. (2021) observed that yield tended to increase with the level of UV reduction. In the present study, the fact that KLP and UVO had higher average yields than the more transmissive films on white mulch (except UVT in 2016) generally aligns with this observation. Lastly, as part of this collaborative project, Anderson et al. (2019) evaluated the same films on white mulch in Minnesota, which showed that fruit yield followed the same pattern in both locations, with higher yields under UVT in 2016 and under UVO in 2017.

Runners. One of the most interesting outcomes from this study is that plants produced more runners on black than white or no mulch, and that plants on black mulch produced more runners on open beds than under low tunnels (Fig. 4). A reduction in runners under low tunnels was initially observed by Lewers (2013) and is something we observed during a separate study (Orde and Sideman, 2019a). At that time, Orde and Sideman (2019a) proposed that the decrease in runnering under low tunnels may be related to plant size, as plants were generally smaller under low tunnels, and a moderate to strong relationship was found between plant height and runner initiation $\left(R^{2}=0.82\right.$ and 0.67 for low tunnels and open beds, respectively). However, in almost all cases in the present study, plant size was comparable between open beds and low tunnels, yet plants on black mulch consistently produced greater numbers of runners on open beds than under low tunnels. To us, this outcome suggests three things: 1) plant size was not the primary or only driver behind runnering, 2) for plants on black mulch, the low tunnel environment was directly reducing runnering, and 3) since plants on the open bed cover treatment behaved differently on black mulch and white mulch, mulch color directly affected runnering.

Runner initiation in strawberry is a complex response believed to be largely stimulated by temperature, photoperiod, plant type, and cultivar (Black et al., 2005; Bradford et al., 2010; Durner et al., 1984). Higher temperatures typically result in a greater number of runners, but there is evidence of an interaction between temperature and daylength, and very high temperatures may reduce runnering (Bradford et al., 2010; Durner et al., 1984; Geater et al., 1997). In the present study, average and maximum soil temperatures at a depth of $7.6 \mathrm{~cm}$ were significantly higher under black mulch than under white mulch [22.1 and $20.3{ }^{\circ} \mathrm{C}$ (average) and 27.3 and $24.2^{\circ} \mathrm{C}$ (maximum) for black mulch and white mulch, respectively] (Orde and Sideman, 2019b). Plants were also noticeably larger on black mulch, though only significantly larger than those on beds with no mulch. Darrow (1966) wrote that warmer soil temperatures can encourage the development of a more vigorous root system to support plant establishment and growth, and in turn, more rapid growth can result in a greater number of total runners. Therefore, it is possible that warmer temperatures both directly and indirectly led plants on black mulch to produce more runners.

The fact that all low tunnel films reduced runnering on black mulch compared with the open bed treatment suggests the radiation level on open beds played a role in runnering as well. Durner et al. (1984) noted that greater $P A R$ levels may result in a higher number of runners, and that even when the photoperiod is the same, light intensity can stimulate runnering. Similarly, Kim et al. (2010) found that a greater photosynthetic photon flux density $\left(P P F D ; \mu \mathrm{mol} \cdot \mathrm{m}^{-2} \cdot \mathrm{s}^{-1}\right)$ led to an increased number of runners. It is likely that the $P P F D$ was highest on the unobstructed open beds, but the fact that we did not also observe an increase in runnering on unobstructed white mulch and unmulched beds suggests there was an additive effect on black mulch. It is likely that there were different drivers modulating runnering for different treatment combinations; however, for black mulch, perhaps high soil temperatures, high ambient $P P F D$, and large plant size were somewhat of a "perfect storm" for runner development.

Practically speaking, the outcomes we present related to runnering suggest that plant propagators producing 'Albion' runner tips in a field environment are likely to maximize the number of stolons per plant by cultivating plants on black mulch and traditional open beds. If runners are undesired, as is the case on fruit farms using the plasticulture system where runner removal can be time-consuming and costly (Handley et al., 2009), then runnering of 'Albion' grown on black mulch may be reduced by covering plants with low tunnels. The results from this study suggest that agricultural films ranging in transparency are equally effective for reducing runner production on black mulch. We also show that runner production may be reduced by using white mulch or no mulch in place of black mulch, but that on open beds, these two mulching strategies may reduce marketable yields.

\section{Literature Cited}

Anderson, H.C., M.A. Rogers, and E.E. Hoover. 2019. Low tunnel covering and microclimate, fruit yield, and quality in an organic strawberry production system. HortTechnology 29(5):590598, doi: 10.21273/HORTTECH04319-19.

Ariza, M.T., C. Soria, J.J. Medina-Mínguez, and E. Martínez-Ferri. 2012. Incidence of misshapen fruits in strawberry plants grown under tunnels is affected by cultivar, planting date, pollination, and low temperatures. HortScience 47(11): 
1569-1573, doi: 10.21273/HORTSCI.47.11. 1569.

Berry Global. 2020. Greenhouse films brochure: Tufflite ${ }^{\circledR}$ high tunnel films. 17 Feb. 2020. $<$ https://catalog.berryglobal.com/catalog-images/ 9087_Berry\%20Global\%20Greenhouse\%20Film $\% 20$ Brochure.pdf $>$.

Bais, A.F., R.L. McKenzie, G. Bernhard, P.J. Aucamp, M. Ilyas, S. Madronich, and K. Tourpali. 2015. Ozone depletion and climate change: Impacts on UV radiation. Photochem. Photobiol. Sci. 14(1):19-52, doi: 10.1039/c4pp90032d.

Black, B.L., H.J. Swartz, G.F. Deitzer, B. Butler, and C.K. Chandler. 2005. The effects of conditioning strawberry plug plants under altered red/far-red light environments. HortScience 40(5):12631267, doi: 10.21273/HORTSCI.40.5.1263.

Bradford, E., J.F. Hancock, and R.M. Warner. 2010. Interactions of temperature and photoperiod determine expression of repeat flowering in strawberry. J. Amer. Soc. Hort. Sci. 135(2): 102-107, doi: 10.21273/JASHS.135.2.102.

Capocasa, F., F. Balducci, C. Martellini, and A. Albanesi. 2017. Yield and fruit quality of strawberry cultivars grown in organic farming in the mid-Adriatic area. Acta Hort. 1156:619626, doi: 10.17660/ActaHortic.2017.1156.91.

Caputo, C., M. Rutitzky, and C.L. Ballaré. 2006. Solar ultraviolet-B radiation alters the attractiveness of Arabidopsis plants to diamondback moths (Plutella xylostella L.): Impacts on oviposition and involvement of the jasmonic acid pathway. Oecologia 149(1):81-90, doi: 10.1007/s00442-006-0422-3

Casal, C., C. Vílchez, E. Forján, and B.A. de la Morena. 2009. The absence of UV-radiation delays the strawberry ripening but increases the final productivity, not altering the main fruit nutritional properties. Acta Hort. 842 (abstr.), doi: 10.17660/ActaHortic.2009.842.19.

Collins, W.B. 1966. Floral initiation in strawberry and some effects of red and far-red radiation as components of continuous white light. Can. J. Bot. 44:663-668, doi: 10.1139/b66-079.

Costa, A.F., P.E. Teodoro, L.L. Bhering, M.K. Fornazier, J.S. Andrade, D.S. Martins, and J.S. Zanuncio, Jr. 2017. Selection of strawberry cultivars with tolerance to Tetranychus urticae (Acari: Tetranychidae) and high yield under different managements. Genet. Mol. Res. 16(2):1-10, doi: 10.4238/gmr16029599.

Darrow, G.M. 1966. The strawberry: History, breeding, and physiology. 1st ed. The New England Institute for Medical Research.

Durner, E.F., J.A. Barden, D.G. Himelrick, and E.B. Poling. 1984. Photoperiod and temperature effects on flower and runner development in day-neutral, junebearing, and everbearing strawberries. J. Amer. Soc. Hort. Sci. 109: 396-400.

Durner, E.F. 2017. Long-day and nitrogen conditioning of 'Albion' strawberry (Fragraria x ananassa Duch.) enhances off-season field production. J. Hort. Sci. Biotechnol. 93(3):296305, doi: 10.1080/14620316.2017.1370985.

Espí, E., A. Salmerón, A. Fontecha, Y. Garcia, and A.I. Real. 2006. Plastic films for agricultural applications. J. Plast. Film Sheeting 22:85-101, doi: 10.1177/8756087906064220.

Fagherazzi, A.F., F. Grimaldi, A.A. Kretzschmar, A.R. Molina, M.A. Gonçalves, L.E.C. Antunes, G. Baruzzi, and L. Rufato. 2017. Strawberry production progress in Brazil. Acta Hort. 1156:937940, doi: 10.17660/ActaHortic. 2017.1156.138.

Fiola, J. 1995. Final report for LNE95-057: Improving the profitability - adaptation of the high-density strawberry production system for the Northeast.
SARE. 17 Feb. 2021. <https://projects.sare.org/ sare_project/lne95-057/?ar=1995 $>$.

Fletcher, J.M., A. Tatsiopoulou, P. Hadley, F.J. Davis, and R.G.C. Henbest. 2004. Growth, yield and development of strawberry cv. 'Elsanta' under novel photoselective film clad greenhouses. ISHS Acta Hort. 633: doi: 10.17660/ ActaHortic.2004.633.11.

Folta, K.M. and K.S. Childers. 2008. Light as a growth regulator: Controlling plant biology with narrow bandwidth solid-state lighting systems. HortScience 43(7):1957-1964, doi: 10.21273/HORTSCI.43.7.1957.

Galletta, G.J. and R.S. Bringhurst. 1990. Strawberry management, p. 109-112. In: G.J. Galletta and D.G. Himekick (eds.). Small fruit management. Prentice Hall, Englewood Cliffs, NJ.

Geater, C.A., G.R. Nonnecke, W.R. Graves, A.S. Aiello, and C.A. Dilley. 1997. High root-zone temperature inhibits growth and development of fragaria species 1. Fruit Var. J. 51(2):94-101.

Hancock, J. and D. Simpson. 1995. Methods of extending the strawberry season in Europe. HortTechnology 5(4):286-290.

Handley, D.T., J.F. Dill, and R.E. Moran. 2009. Prohexadione-calcium applications to suppress runner growth in strawberries grown in a plasticulture system. Acta Hort. 842:801-804 (abstr.), doi: 10.17660/ActaHortic.2009.842.176.

Henschel, J.M., J.T.V. Resende, P.C. Giloni-Lima, A.R. Zeist, R.B. Lima Filho, and M.H. Santos. 2017. Production and quality of strawberry cultivated under different colors of low tunnel cover. Hort. Bras. 35:364-370, doi: 10.1590/ s0102-053620170308.

Kakani, V.G., K.R. Reddy, D. Zhao, and K. Sailaja. 2003. Field crop responses to ultraviolet-B radiation: A review. Agr. For. Meteorol. 120:191-218, doi: 10.1016/j.agrformet.2003.08.015.

Karlsson, M.G. and J.W. Werner. 2011. High tunnel covering materials for northern field production. Acta Hort. 893:1333-1340, doi: 10.17660/ActaHortic.2011.893.157.

Kim, S.K., M.S. Jeong, S.W. Park, M.J. Kim, H.Y. Na, and C. Chun. 2010. Improvement of runner plant production by increasing photosynthetic photon flux during strawberry transplant propagation in a closed transplant production system. Kor. J. Hort. Sci. Technol. 28(4):535-539.

Kochka, M. 2016. Strawberry production in Hampshire. Univ. of New Hampshire, Durham, M.S thesis. ProQuest number: 10246374. < https:// scholars.unh.edu/cgi/viewcontent.cgi?article= 1899 \& context $=$ thesis $>$.

Krischik, V. and J. Davidson. 2013. IPM (integrated pest management) of Midwest landscapes v. turf pests. University of Minnesota. 25 Jan. 2021. <http://cues.cfans.umn.edu/old/ Web/247OrientalBeetle.pdf $>$.

Lamnatou, C. and D. Chemisana. 2013. Solar radiation manipulations and their role in greenhouse claddings: Fluorescent solar concentrators, photoselective and other materials. Renew. Sustain. Energy Rev. 27:175-190, doi: 10.1016/j.rser. 2013.06.052.

Lamont, J.L., Jr. 1993. Plastic mulches for the production of vegetable crops. HortTechnology 3(1):35-39, doi: 10.21273/HORTTECH. 3.1.35.

Lantz, W., H. Swartz, K. Demchak, and S. Frick. 2010. Season-long strawberry production with. 2021. everbearers for northeastern producers. Univ. Maryland Ext. EB 401:17. $<$ https://www.sare.org/wp-content/uploads/ Everbearing-Strawberry-Guide.pdf $>$.

Laugale, V., S. Dane, L. Lepse, S. Strautina, and I. Kalnina. 2017. Influence of low tunnels on strawberry production time and yield. Acta Hort. 1156:573-578, doi: 10.17660/ActaHortic.2017. 1156.85 .

Lewers, K. 2013. Strawberry season extension using low tunnels. 17 Feb. 2021.<http://www. hort.cornell.edu/expo/2013proceedings.php $>$.

Lewers, K.S., D.H. Fleisher, and C.S.T. Daughtry. 2017. Low tunnels as a strawberry breeding tool and season-extending production system. Intl. J. Fruit Sci. 17(3):233-258, doi: 10.1080/ 15538362.2017.1305941.

Lewers, K.S., D.H. Fleisher, C.S.T. Daughtry, and B.T. Vinyard. 2020. Low-tunnel strawberry production: Comparison of cultivars and films. Intl. K. Fruit Sci. doi: 10.1080/15538362.2020. 1768616.

Mays, J. and S. Gu. 2018. Nitrogen affects the growth and yield of day-neutral strawberry 'Albion' in low tunnels. HortScience 53(9): S141 (abstr.).

Mazza, C.A., H.E. Boccalandro, C.V. Giordano, D. Battista, A.L. Scopel, and C.L. Ballaré. 2000. Functional significance and induction by solar radiation of ultraviolet-absorbing sunscreens in field-grown soybean crops. Plant Physiol. 122:117-125, doi: 10.1104/pp.122.1.117.

McGuire, R.G. 1992. Reporting of objective color measurements. HortScience 27(12):1254-1255.

Orde, K.M. and R.G. Sideman. 2019a. Low tunnel and cultivar effects on day-neutral strawberry yield and characteristics in New Hampshire. HortTechnology 29(6):795-810, doi: 10.21273/ HORTTECH04317-19.

Orde, K.M. and R.G. Sideman. 2019b. Influence of photoselective film and mulch color on air and soil temperatures in a low tunnel strawberry production system. GreenSys International Symposium on Advanced Tech. and Mgt. for Innovative Greenhouses. Angers, France. June 16-20, 2019

Orde, K.M. and R.G. Sideman. 2021. Winter survival and second-year spring yields of day-neutral strawberry are influenced by cultivar and the presence of low tunnels. HortTechnology 31(1):77-88, doi: 10.21273/HORTTECH04 734-20.

Paul, N.D., R.J. Jacobson, A. Taylor, J.J. Wargent, and J.P. Moore. 2005. The use of wavelengthselective plastic cladding materials in horticulture: Understanding of crop and fungal responses through the assessment of biological spectral weighting function. Photochem. Photobiol. 81(5): 1052-1060, doi: 10.1562/2004-12-06-RA-392.

Petran, A., E. Hoover, L. Hayes, and S. Poppe. 2016. Yield and quality characteristics of day-neutral strawberry in the United States upper Midwest using organic practices. Biol. Agr. Hortic. 33(2): 1-16, doi: 10.1080/01448765.2016.1188152.

Pike, D. 2011. Day-neutral strawberries: Making it work. New England Veg. Fruit Conf. Trade Show Proc. 2011:75-76. 17 Feb. 2021. $<$ https://newenglandvfc.org/sites/newenglandvfc. org/files/content/proceedings2011/strawberrypike.pdf $>$

Pritts, M. and D. Handley. 1998. Strawberry production guide for the northeast, midwest, and eastern Canada. Northeast Reg. Agr. Eng. Serv. (NRAES), Ithaca, NY.

Pritts, M. and L. McDermott. 2017. Protected culture for strawberries using low tunnels. Cornell Univ. Ithaca, NY. 17 Feb. 2021. <http://www.hort. cornell.edu/fruit/pdfs/low-tunnel-strawberries. pdf $>$.

Pritts, M. 2017. Protected culture for berries, low and high tunnel research. New Jersey Agr. Convention Trade Show. 17 Feb. 2020. $<$ https://www.youtube.com/watch?v=5ErlnTZ NuxM $>$. 
Rein, M.J. and M. Heinonen. 2004. Stability and enhancement of berry juice color. J. Agr. Food Chem. 52:3106-3114, doi: 10.1021/jf035507i.

Resende, J.T.V., R.G.F. Morales, M.V. Faria, A.L.L. Rissini, L.K.P. Camargo, and C.K. Camargo. 2010. Produtividade e teor de solidos soluveis de frutos de cultivares de morangueiro em ambiente protegido. Hort. Bras. 28:185-189, doi: 10.1590/ S0102-05362010000200008.

RKW. Group, 2020. Kool Lite Plus greenhouse film. 17 Feb. 2020. <https://rkw-group.com/ portfolio/kool-lite-plus/ $>$.

RKW Hyplast NV. 2015. Analytic data sheet on temperature reducing greenhouse poly. Hortdaily. 17 Feb. 2021. <https://www.hortidaily.com/article/ 6015393/analytic-data-sheet-on-temperaturereducing-greenhouse-poly/ $>$.

Rosati, P. 1990. The strawberry in Europe. In: A. Dale and J. Luby (eds.). The strawberry into the 21 st century. Timber Press, Portland, OR.

Samtani, J.B., C.R. Rom, H. Friedrich, S.A. Fennimore, C.E. Finn, A. Petran, R.W. Wallace, M.P. Pritts, G. Fernandez, C.A. Chase, C. Kubota, and B. Bergefurd. 2019. The status and future of the strawberry industry in the United States. HortTechnology 29(1):11-24, doi: 10.21273/ HORTTECH04135-18.

Schreiner, M., M. Wiesner-Reinhold, S. Balkermann, F.S. Hanschen, and S. Neugart. 2017. UV-Binduced changes in secondary plant metabolites. In: B.R. Jordan (ed.). UV-B radiation and plant life. CAB Intl. Wallingford, Oxfordshire, UK and Boston, MA.

Shogren, R.L. and R.C. Hochmuth. 2004. Field evaluation of watermelon grown on paper-polymerized vegetable oil mulches. HortScience 39(7):1588 1591, doi: 10.21273/HORTSCI.39.7.1588.

Singh, A., A. Syndor, B.C. Deka, R.K. Singh, and R.K. Patel. 2012. The effect of microclimate inside low tunnels on off-season production of strawberry (Fragaria $\mathrm{x}$ ananassa Duch.). Scientia Hort. 144:36-41, doi: 10.1016/j.scienta.2012.06.025.

Soliman, M.A., H.A. Abd El-Aal, R.A. Mohmed, and N.N. Elhefnawy. 2015. Growth, fruit yield and quality of three strawberry cultivars as affected by mulch type and low tunnel. Alexandria Science Exchange J. 36(4):402-414, doi: 10.21608/asejaiqjsae.2015.2963.

Tsormpatsidis, E., M. Ordidge, R.G.C. Henbest, A. Wagstaffe, N.H. Battey, and P. Hadley. 2011. Harvesting fruit of equivalent chronological age and fruit position shows individual effects of UV radiation on aspects of the strawberry ripening process. Environ. Exp. Bot. 74(1):178-185, doi: 10.1016/j.envexpbot.2011.05.017.

University of New Hampshire. 2016. Commercial fruit soil report. Univ. New Hampshire Cooperative Extension.

U.S. Department of Agriculture National Agricultural Statistics Service. 2018. New England vegetable and strawberry report, 2017 crop. U.S. Dept. Agr., Washington, DC:1-12.

Van Sterthem, A., Y. Desjardins, L. Gauthier, Y. Medina, and A. Gosselin. 2017. Use of low tunnels to improve the productivity of day-neutral strawberry plants under the Quebec climatic conditions. Acta Hort. 1156:555-562, doi: 10.17660/ActaHortic.2017.1156.82.

Vincent, C., B. Panneton, and F. Fleurat-Lessard. 2013. Physical control methods in plant protection. Springer-Verlag.

Weber, C., R. Gassier, K. Kuehn, and M.P. Pritts. 2018. Yield of day-neutral strawberries grown under low tunnels is affected by planting date. HortScience 53:S171 (abstr.).

Willden, S.A., K.D. Cox, M.P. Pritts, and G.M Loeb. 2021. A comparison of weed, pathogen and insect pests between low tunnel and openfield grown strawberries in New York. Crop Prot. 139: doi: 10.1016/j.cropro.2020.105388.

Yoshioka, Y., M. Nakayama, Y. Noguchi, and H. Horie. 2013. Use of image analysis to estimate anthocyanin and UV-excited fluorescent phenolic compound levels in strawberry fruit. Breed. Sci. 63:211-217, doi: 10.1270/jsbbs.63.211.

Zahedi, S.M. and H. Sarikhani. 2016. Effect of farred light, temperature, and plant age on morphological changes and induction of flowering of a 'June-bearing' strawberry. Hort. Environ. Biotechnol. 57(4):340-347, doi: 10.1007/s135 80-016-0018-8. 